\title{
A Samaritan merchant and his friend, and their friends: Practicing life-giving theology
}

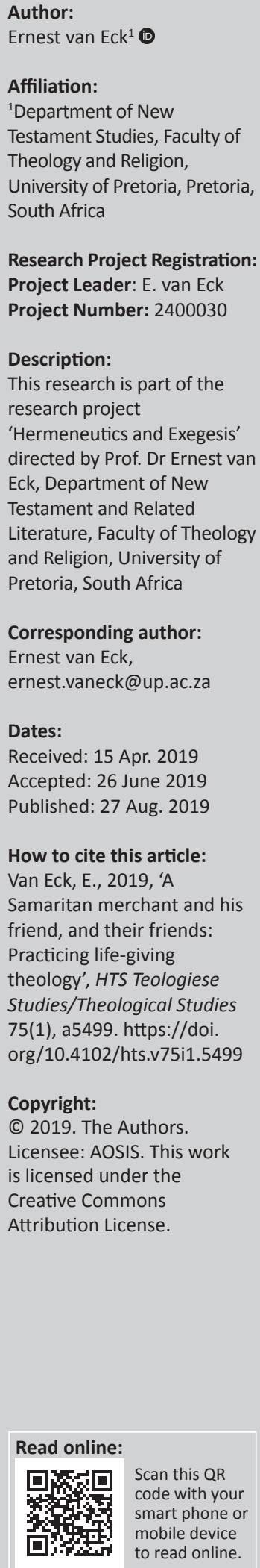

The Department of New Testament and Related Literature (formerly the Department of New Testament Studies) for the past 100 years has had a proud tradition of practicing life-giving theology. From very early on, several members of the department were critical voices against exclusive and discriminatory narratives of their time. Representing the voices of the disadvantaged, excluded and marginalised people, they critiqued systemic injustices, envisaged inclusive believing communities, advocated an open society with equal opportunities for all and called for social justice. This article shows that the current members of the department are upholding this proud tradition in their research and publications. Common to the current trend in the department is the avoidance of a literal reading of texts by paying attention to the historical and social contexts of texts and using all possible approaches in reading the text from as many angles as possible. This approach has led to new avenues to reread texts with concomitant new interpretations. As an example of this approach, a rereading of the so-called parable of the Samaritan is presented, challenging its dominant and universally accepted interpretation. The article concludes with a statement of intent linked to the vision of the department, that is, to practice and teach life-giving theology that counters individualised and unreflective ways of living by articulating and embracing a theology that leads to a flourishing life for all creation.

Keywords: Parables; The Samaritan; Reformed Church of Africa; Dutch Reformed Church; Apartheid; Life-giving Theology.

\section{Introduction}

The Department of New Testament and Related Literature (formerly the Department of New Testament Studies), since 1917, has a proud tradition of practicing life-giving theology, often (almost always) in the face of severe critique and adversity. From their academic publications, requested denominational reports, popular contributions and newspaper articles, it is clear that several members of the department, from very early on, were critical voices against dominant grand narratives that perpetuated exclusion and discrimination. As the voices of the disadvantaged, excluded and marginalised, they critiqued systemic injustices, envisaged inclusive believing communities, advocated an open society with equal opportunities for all and called for social justice.

For the sake of time, two examples in this regard will suffice. Since 1904, up to 2016, the Netherdutch Reformed Church of Africa (NRCA), from an ecclesiological point of view, understood itself to be a 'people's church' (or 'ethnic church'), first embodied by Article II (1904), and then by Article III (1951), and later, in 1997, by Ordinance 4 of the NRCA's church order. This ecclesiological self-understanding was exclusive in intent, with a clear purpose, to exclude those 'who are not like us'. The first voice in the NRCA (and the then Department of New Testament Studies, Section A) against this ecclesiological self-understanding was that of Greyvenstein, who, in 1936, argued in the monthly official newsletter that the church of Christ consisted of all believers, including those from all generations and nations. Later, in 1943, he also stated that discrimination in terms of race and the feeling of superiority over those from different ethnicities are hindrances towards an universal humanity. These convictions, needless to say, did not go down well.

In 1947, Albert Geyser, who succeeded Greyvenstein, reiterated that the New Testament teaches an inclusive and universal church, and that the church, if it wants to heed to its call, had to transcend national and geographical boundaries. In 1948, he repeated this conviction; that the main task of

Note: Inaugural address delivered on 13 March 2019 as newly appointed Head of Department. Prof. Ernest van Eck was appointed as Head: Department of New Testament and Related Literature on 01 October 2018. 
the church is to confess Christ to all, and not to serve nationalpolitical and ethnic interests. In 1960, in the face of severe adversity, especially from the side of the then church leadership, Geyser again took the NRCA to task regarding its exclusive ecclesiology, describing the church as a manifestation of ideologia in proclaiming a limited and qualified love towards those 'who are not like us'. This, Geyser lamented, was nothing else than hate, and when ideologia is dressed in nationalism, it is nothing else but idolatry.

A year later, in 1961, Geyser condemned the fact that the gross majority of members of the church use Scripture to support racial segregation in church and society. As a minority voice in the then NRCA, these points of view eventually lead to his excommunication by the church. Only 23 years later, it was again a member of the department, Andries van Aarde, who openly in publications and in meetings of the church consistently voiced his disapproval of the NRCA's exclusive ecclesiological self-understanding. In 2009, Van Eck (appointed in 2006) added his voice to that of Van Aarde, arguing that for Jesus, Paul and the author of acts, in spite of the fact that in antiquity group identity was based on cultural ethnicity, ethnicity meant nothing when it comes to being in God's presence, being part of the early Christ followers or being part of any local (Pauline) congregation. The New Testament, simply speaking, bears witness to an inclusive ecclesiology.

The NRCA finally, in 2010, adopted a resolution in which the church, for the first time, officially stated that supporting Apartheid by means of Scripture was wrong. This resolution was the result of a press statement by five theologians of the NRCA (Johan Buitendag, Yolanda Dreyer, Jimmie Loader, Andries van Aarde and Ernest van Eck), calling on the NRCA to state that it was wrong, for so many years, to support Apartheid on the basis of Scripture. It is needless to say that these five theologians, yet again, in the preceding year, had to fend off a case of heresy made against them for their 'unbiblical' point of view.

With regard to the Dutch Reformed Church (DRC), Prof. Andrie du Toit, also from the then Department of New Testament Studies, played a major role (with seven other academics, including Prof. Muller and Heyns from the Faculty of Theology) in paving the way for the DRC to move from an exclusive to an inclusive ecclesiological selfunderstanding. In 1980, Du Toit, with seven other theologians of the DRC, released a witness in which they called upon the church to formally renounce Apartheid in church and society.

Interestingly, amidst serious opposition in the DRC, 86 theology students from the faculty (Section B) released a declaration on 20 March 1981, published in Beeld, in which they supported the 8 theologians and the content of the witness. Today, it is generally accepted that this witness was the prophetic voice indicating that the NRC needed to later move from an exclusive ecclesiological self-understanding to an inclusive believing community.
My second example relates to the discrimination in church and society against persons with a homosexual orientation, especially with regard to entry into the ministry. In the NRCA, the General Assembly of 2016 finally opened its doors for homosexual persons without any reservation. Homosexual persons now could enter the ministry in the NRCA. In the DRC, the jury is still out, with a very recent 'yes' turned into a 'no'.

Focusing on the contributions made to this debate by New Testament scholars from the faculty, the publications of Du Toit, Steyn and Van Eck can be mentioned. Du Toit correctly indicated that the main problem of the debate on homosexuality in the church is that a modern understanding of a phenomenon or topic is read back into the New Testament as if the exact same phenomenon is under discussion (ethnocentrism). Steyn and Van Eck have come to the same conclusion, arguing that homosexuality, as understood today, is a modern construct not found in the New Testament, and that the texts on 'homosexuality' in the New Testament cannot simply, on a one-to-one basis, be used to exclude homosexual persons from the ministry of the church. These contributions, at least indirectly, played a role in the most recent resolution taken by the NRCA not to make sexual orientation a determinant when someone wants to join the ministry, and probably will play a role in the current debates in the DRC on the unlimited inclusion of homosexual persons, and persons of all sexual orientations, in the ministry of the church.

These contributions made by members of the department in the past 100 years are the result of a historical, critical and close reading of the text. This includes always starting with the Greek text, taking the historical and social contexts of the text seriously, attending to possible text-critical issues and using all possible approaches in reading the text from as many angles as possible. Very clearly, a literal reading of the text should be avoided, with the first focus on what the text most probably meant. Only then it is asked what a specific text may mean in any given (new) context. This approach not only led to new avenues to reread texts with concomitant new interpretations, but it also challenges traditional readings. Only by questioning, challenging and rereading can deconstruction take place, and new meaning and life can break through.

From the above, this is clear. This is also the way in which the current members of the department see the respective contributions they are making when it comes to their exegetical work; it must lead to life-giving theology. In my own work, especially on the parables, this has been my focus since 2006. To illustrate what I mean by this, I now will offer a rereading of the well-known parable of the 'Good Samaritan', challenging its universally accepted stock interpretation. Because the meaning of this parable is so obvious, almost all parable scholars will argue that it simply cannot be challenged. I believe it can, with a surprising result: the breaking down of stereotypes that perpetuate discrimination and exclusion. 


\section{Interpreting the Samaritan: Current lenses}

Almost all interpretations of the parable of the Samaritan are in agreement on three points: the description of the Samaritan, the identification of the three-step structure of good storytelling in the parable and the surprise in the story.

Firstly, almost without exception, the Samaritan is described as a despised and hated person, part of a people that was the natural and sworn enemy of the Jews (see, e.g., Barclay 1970:81; Donahue 1988:130; Jeremias 1972:204; Meier 1991:207; Scott 1989:197, 200; Wright 2015:107). For most, Jews and Samaritans had 'notoriously bad relations' (Snodgrass 2008:345), and labels such as Gentile, religious apostate (Hultgren 2000:98, 131), foreigner, unbeliever, idolater (Zimmermann 2015:309), heretic or schismatic (Bailey 1983:48) are regularly used to describe the Samaritan. The alleged hostility that existed between Jew and Samaritan is depicted as something that was irreconcilable (Jeremias 1972:204). So bad was the relationship between these two parties that, according to Stein (1981:76), Jews as a normal practice cursed the Samaritans, and went to the extreme to avoid all contact with. As such, the term 'good Samaritan', according to Crossan, was a 'cultural paradox, a social contradiction in terms' (Crossan 2012:60). ${ }^{1}$

Secondly, a broad consensus exists that the parable follows the so-called 'rule of three' of good storytelling.

Traditionally, three traditional divisions existed among the Jews, namely priests, Levites and all Israel (Hultgren 2000:97-98; Jeremias 1972:204; Wright 2015:108). ${ }^{2}$ The temple in Jerusalem was served by these three classes (i.e. priests, Levites and laymen), and Jewish stories in the 1st century always introduced a priest, then a Levite and then a Jewish layman (Bailey 2008:292, 294). Therefore, when a story was told that first introduced a priest, and then a Levite, both traveling from Jerusalem to Jericho most probably returning home after officiating in the

1.The reasons for this pejorative description of the Samaritan are manifold, including historical factors and religious differences. Tension between Samaritans and Israelites started in 922 BCE after the death of Solomon, when Israel split into the northern and southern kingdoms when the northern kingdom (Samaria) led by Jeroboam revolted against Rehoboam. The Assyrians captured the northern kingdom in $722 \mathrm{BCE}$, and brought immigrants from foreign lands to live in Samaria (see 2 Ki 17:24-41). These peoples worshipped foreign gods, and over time married Samaritans. As a result, the Jews considered Samaritans as half-breeds, the people who lost their result, the Jews considered Samaritans as half-breeds, the people who lost their racial purity. The Babylonians captured the southern kingdom in 586 $\mathrm{BCE}$, and after their return, under the leadership of Haggai and Zechariah, began to rebuild the temple in Jerusalem. The Samaritans offered to help, but their help was declined, because of their foreign marriages, they had lost, in the eyes of the returning Jews, the right to be regarded as Jews in any way. For the Jews from the south (Judea), the Samaritans had no continuing place in the covenant of the Hebrew people. In reaction to the refusal for help, the Samaritans sought to hinder the reconstruction of the Jerusalem temple, and build their own temple at Gerezim near Shechem in the late 4 th century BCE. They rejected the Old Testament as a whole, and their scripture was a redaction of the Pentateuch, which is known as the Samaritan Pentateuch. In the 2nd century, the Samaritans helped the Syrian rulers in their wars against the Jews, and in $128 \mathrm{BCE}$, John Hyrcanus, the Jewish Hasmonean king and high priest, burnt the Samaritan temple on Mount Gerezim. In the early 1st century (somewhere between 6 and $9 \mathrm{CE}$ ), the Samaritans scattered the bones of corpse throughout the court of the temple during Passover, defiling the temple and preventing the celebration of the feast. From their side, the Jews publicly cursed the preventing the celebration of the feast. From their side, the Jews publicly cursed the Samaritans in their synagogue services, and petitioned for their exclusion from eternal life. Scholars who reject the biblical account in 2 Kings as unhistorical, see burning down of the temple in 128 BCE (see Schiffman 1985:324).

2.See, for example, 2 Samuel 7;19, 2 Chronicles 35:2-3, Ezra 10:5, Nehemiah 11:3 and 20, m. Gițtin 5:8 and m. Horayot 3.8 . temple, ${ }^{3}$ the expectation would have been that the third character in the story was to be an ordinary Israelite (Jeremias 1972:204; Hultgren 2000:97-98; Scott 1989:198).

Thirdly, the surprise or shock in the parable. The negative perception of Samaritans by the Jews, combined with the 'rule of three' or 'three step-structure' of good storytelling, most commentators on the parable argue, lead to the surprise in the parable. The third person arriving on the scene is not the suspected ordinary Israelite, but a hated Samaritan. This, according to most interpreters, is not only a surprise (Hultgren 2000:98), but 'a major shock' (Donahue 1988:130): A Samaritan arriving on the scene instead of an Israelite is completely unexpected (Jeremias 1972:204), a scandalous comparison (Scott 1989:198), a shocking counter example (Blomberg 2012:301), a 'jarring surprise' for the hearers (Wright 2015:108) or a development in the parable that explodes in the faces of the listeners (Bailey 2008:294).

\section{Samaritans as despised and hated persons, enemies of the Jews: Assessing the evidence}

In all cases, the negative depiction of Samaritans by interpreters of the parable, when it comes to literary evidence, is based on two texts, namely m. Niddah 4.1 and m.Šebi it 8.10 (see, e.g. Scott 1989:197; Stiller 2005:78). M. Niddah 4.1 reads as follows (Danby 2011):

The daughters of the Samaritans are [deemed unclean as] menstruants from their cradle; and the Samaritans convey uncleanness to what lies beneath them in like degree as [he that has a flux conveys uncleanness] to what lies above him, since they have connection with menstruants. (p. 748)

Missing from citing this evidence, Levine (2014:100) rightly indicates, is citing the next passage, $m$. Niddah 4.2 (Danby 2011):

The daughters of the Sadducees, if they follow after the ways of their fathers, are deemed like to women of the Samaritans; but if they have separated themselves and follow after the ways of the Israelites, they are deemed like to the women of the Israelites. (p. 748)

Clearly, as m. Niddah 4.2 indicates, 'the Mishna cannot possibly reflect the view of "all Jews"' (Levine 2014:100). In addition, missing from citing evidence in most cases is $b$. Niddah $31 \mathrm{~b}$, in which the Tannaic rabbis reflect on $m$. Niddah 4.1, stating that when a discharge from Israelite women (our daughters) is observed, they should also be regarded as unclean, and when no discharge from Samaritan women (their daughters) is observed, they should not be regarded as unclean. ${ }^{4}$

3.See Luke 10:30-32: The man who fell among the robbers was going down from

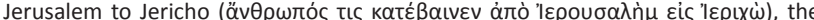

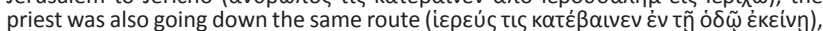

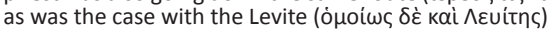

4.M. Niddah 7.4, which states that a place of uncleanness, 'that belongs to Samaritans convey uncleanness by overshadowing, since they bury abortions there', are sometimes also cited to indicate the uncleanness of the Samaritans. M. Niddah 7.5, however, states that Samaritans are to be believed when they state that abortions were not buried at a certain place. All translations of the Mishna presented here are taken from Danby (2011). 
The second text cited as evidence for the hated relationship between Jew and Samaritan is m. Šebi it 8.10 (see, e.g. Bailey 1983:48), which reads as follows (Danby 2011):

Moreover they declared that before him that R. Eliezer used to say: He that eats the bread of the Samaritans is like to one that eats the flesh of swine. (p. 49)

What, however, is not cited, is the explicit rejection of this view of the Samaritans by Rabbi Akiba, as m. Šebi it 8.10 continues: 'He replied: Hold your peace; I will not say to you what R. Eliezer has taught concerning this' (Danby 2011:49). Clearly, in $m$. Šebi it 8.10, the extreme statement of Rabbi Eliezer is explicitly rejected by Rabbi Akiba, and, importantly, in the same passage (Snodgrass 2008:347).

Contrary to the so-called hated relationship between Jews and Samaritans, literary evidence from the Tannaic literature, the Mishna, the two Talmuds and Tosefta on the position of the Samaritans are clear: The Samaritans, contrary to their stereotyped description, were regarded as Israelites. B. Ketubot 27a, for example, states that a 'Samaritan is equivalent to a gentile', the words of Rabbi. Rabban Simeon b.

Gamaliel says, 'A Samaritan is equivalent to an Israelite for all intents and purposes'. Y. Demai 9 reads 'Rabbi Rabban Simeon b. Gamaliel says, "Samaritans are classified as Israelites for all purposes"', as is the case in y. Ketubot 3.1:

This rule accords with him who said, 'A Samaritan is equivalent to an Israelite in all regards'... Rabban Simeon b. Gamaliel says, 'A Samaritan is equivalent to an Israelite for all intents and purposes'. (see also $t$. Ter. $4.12,14)^{5}$

Several other examples from the Tannaic literature confirm that the rabbis saw the Samaritans as trustworthy Israelites. Samaritans were permitted to participate in the Jewish cultic meal ( $m$. Ber. 7.1), ${ }^{6}$ permitted to recite the blessing (benediction) during the meal (m. Ber. 8.7-8), ${ }^{7}$ allowed to pay tithes (see $m$. Ter. $3.9 ; 4.14){ }^{8}$ act as midwives or nurses to Israelite children (b. 'Abod. Zar. 15b) ${ }^{9}$ and were even allowed to circumcise Israelites (Kutim 12; b. 'Abod.

5.T. Terumot 4.12 reads that a 'A Samaritan is [treated] like an Israelite', as is the case in $t$. Terumot 4.14 (see Neusner 2002:157). All translations of the Tosefta presented here are taken from Neusner (2002).

6.If three eat together, they must say the Common Grace. If one of them ate demaiproduce, or First Tithe from which Heave-offering had been taken, or Second Tithe produce, or First Tithe from which Heave-offering had been taken, or Second Tithe food, or [if one that ate was] a Samaritan, they may be included [to make up the food, or [if one that ate was] a Samaritan, they may be
number needed] for the Common Grace' (m. Ber. 7.1).

7.'If a man ate and forget to say the Benediction, the School of Shammai say $[s]$... and the School of Hillel say[s] ... If wine is brought after the food, and there is but that one cup, the School of Shammai say[s] ... And the School of Hillel say[s]: The Benediction is said over the food and then over the wine. They may answer 'Amen' after and Israelite who says a Benediction, but not after a Samaritan until they have heard the whole Benediction (m. Ber. 8.7-8).

8.T. Terumot 3.9 reads: 'Heave-offering or Tithes or Hallowed Things that are given by ... a Samaritan are valid' (Danby 2011:55). T. Terumot 4.14 carries the same idea: 'A Samaritan who separated heave-offering and gave it to a [Samaritan] priest that which he has separated is a [valid] heave-offering' (Neusner 2002:157).

9.B. Abodah Zarah 15b reads: 'An Israelite girl serves as a midwife and gives suck to the child of a Samaritan woman. And a Samaritan woman serves as midwife and gives suck to an Israelite child'.
Zar. 26b). ${ }^{10}$ Israelites, in their turn, were permitted to marry Samaritans (b. Qidd. 75b), ${ }^{11}$ eat cooked food prepared by Samaritans (y. 'Abod. Zar. 5.4), ${ }^{12}$ buy wheat (m. Demai $3.4 ; 5.9)^{13}$ and wine (m. Demai 7.4$)^{14}$ from them, conduct business with Samaritans (m. Demai 6.1; Kutim 13) ${ }^{15}$ and even be business associates (b. Niddah 33b). ${ }^{16}$ Moreover, some rabbis considered the Samaritans, when it came to certain commands of the law, as more scrupulous than the Jews (b. Git 10a; b. Qidd. 76a; b. Ber. 47b). ${ }^{17}$

If this positive picture of the Samaritans indeed was the case, some would immediately argue what then to make of texts such as t. Terumot 4.12 and 14, b. Ketubot 27a, y. Demai 9 and y. Ketubot 3.1 in which it is stated that Samaritans should be treated as Gentiles or to be considered as equivalent to gentiles? Or $m$. Qiddušin 4.3, which indicates that marriage with Samaritans is forbidden, or m. Qiddušin 1.5 that states that the half-shekel temple tax should not be accepted from Samaritans?

Initially, it was thought that the references to Samaritans in Mishna, the Talmuds, Tosefta and the minor tractates show evidence of non-agreement among the rabbis concerning the Samaritans. While some saw them as Israelites, others considered them to be on a rank lower than the Israelites (see, e.g., b. Qidd. 75a-76a; b. B. Qam. 38b; b. Sanh. 85b; b. Hul. 3b; b. Nid. 56b, Kutim 27). This, however, does not seem to be the

10.'An Israelite may circumcise a Samaritan, and a Samaritan an Israelite' (Kutim 12; transl. from Hjelm 2000:107). B. 'Abod. Zar. 26b reads: '“An Israelite may circumcise a Samaritan, but a Samaritan may not circumcise an Israelite, because he performs the act of circumcision for the sake of Mount Gerizim," the words of R. Judah. Said to him R. Yosé, "Where do we find an act of circumcision [performed by a to him R. Yosé, "Where do we find an act of circumcision [performed by a
Samaritan] which is not for the sake of the covenant, but which is for the sake of Samaritan] which is not for the sake
Mount Gerizim, until he is dead?"'.

11.'R. Aqiba maintains that Samaritans are authentic converts, and priests who are mixed up with them are fit priests, as it is said, 'And they made up to them from among themselves priests of the high places' (2 Ki. 17:32), and said Rabbah bar Hannah said R. Yohanan, 'That was from the choicest of the people'(b. Qidd. 75b).

12.y. 'Abodah Zarah 5.4 reads: 'R. Judah bar Pazzi in the name of R. Ammi: "A roasted egg prepared by Samaritans, lo, this is permitted." R. Jacob bar Aha in the name of R. Eleazar: "Cooked foods prepared by Samaritans, lo, these are permitted"'.

13.'If a man brought his wheat to a miller that was a Samaritan ... its condition remains as before in what concerns Tithes and Seventh Year produce; but if he brought it to a miller that was a gentile, [after it has been ground], it is accounted demaiproduce' ( $m$. Demai 3.4)

14.If a man buys wine among Samaritans, he may say, 'Let two logs which I shall set apart be Heave-offering, and ten [others] [First] Tithe and nine Second Tithe': then, after he has set apart the redemption money, he may drink' (m. Demai 7.4; see also b. Erubin 36b; b. Yoma 55b; b. Gițten 28a).

15. If a man leased a field from an Israelite ... or Samaritan, he must divide [the produce] in their presence' ( $m$. Demai 6.1 ). Kutim 13 reads: 'We may lodge a beast in a Samaritan inn, or hire a Samaritan to go behind our cattle, or hand over our cattle to a Samaritan herdsman. We commit a boy to a Samaritan to teach him a trade. We associate and converse with them anywhere, which is not the case with the Gentiles' (see also b. 'Abod. Zar. 15b; transl. from Hjelm 2000:110).

16.'Said R. Pappa, "May it be God's will that this bull may be eaten in peace. Here with what sort of case do we deal [in the Mishnah which implies that we do not burn priestly rations in this context by reason of doubt]? With a Samaritan who is an associate [in that he observes the rules of cultic cleanness even in connection with ordinary food]"' (b. Nid. 33b).

17.'Unleavened bread prepared by Samaritans is permitted for use on Passover, and a person carries out the obligation for eating such unleavened bread on Passover by eating Samaritan unleavened bread. But R. Eleazar prohibits doing so, for they are by no means expert in the details of the laws of unleavened bread. Rabban Simeon b. Gamaliel says, 'Any religious duty that the Samaritans preserved they observe with far great[er] punctiliousness than Israelites' (b. Git 10a; see also $t$. Pesah 2:3). with far great [er] punctiliousness than Israelites' (b. Git 10a; see also t. Pesah 2:3). B. Qiddušin 76a reads: 'The unleavened bread prepared by Samaritans is permitted to Israelites on Passover, and a person fulfils his obligation to eat unleavened bread on Passover by eating that unleavened bread ... R. Simeon b. Gamaliel says, Concerning all religious duties that the Samaritans have taken for themselves are "he Samaritans much better informed even than Israelites"'. B. Berakot 47b states: 'For a master has said, "In the case of any religious duty that the Samaritans have
adopted for themselves, they are most meticulous, more so even than Israelites"'. 
case. Hershkovitz (1940:71-105), in a detailed study of all the Tannaic material pertaining to this question, has convincingly concluded that a development in the attitude of the rabbis towards the Samaritans can be indicated during the Tannaic period; earlier materials consider the Samaritans as Jews, while later sources see the Samaritans as equivalent to nonJews (Schiffman 1985:324).

This shift in attitude towards the Samaritans, Schiffman (1985) argues, most probably occurred soon after the Bar Kochba revolt. This can be indicated, for example, in $t$. Terumot 4.12 and 14 where the opinion that the Samaritans are non-Jews comes from Rabbi Judah the Prince, the son of Rabban Simeon ben Gamaliel (i.e. Simeon II ben Gamaliel II), who flourished in the post-Hadrianic period (i.e. after the Bar Kochba revolt in 132-135 CE; see Schiffman 1985:327). He was born in $135 \mathrm{CE}$ and was one of the prominent Amoraim in the period after 200 CE. The same can be said of $t$. Qiddušin 4.3 and 5.1, which forbid marriage between Jews and Samaritans. As indicated by Lieberman (in Hershkovitz 1940:330), this prohibition is the point of view of Rabbi Eleazer ben Shammua, a third-generation Tanna from after the period of the Bar Kochba revolt. Jews thus only were forbidden to marry Samaritans from some time in the first half of the 2nd century (Hershkovitz 1940:334). In short, a strong case can be made that 'the negative rulings regarding the Samaritans were inserted (into Tannaic literature) by redactors after the time of Simeon ben Gamaliel' (Hershkovitz 1940:344), that is, after 135 CE. Before that, Samaritans were seen as trustworthy Israelites. As put by Hjelm (2000):

Religious as well as social co-existence demanded a clear definition of conditions and demarcation of Samaritans from heathens, who had been understood to be different from Samaritans. When it came to 'food, marriage, cult practice, religious feasts, trade, circumcision, collection of tithes, and so on', Samaritans were still considered to belong to 'the children of Israel'. (p. 105) (see also Schottroff 2006:135; Fagenblat 2011:543) ${ }^{18}$

\section{New lens, new reading}

Taking as a point of departure that Samaritans were seen as trustworthy Israelites, at least at the time Jesus told the parable (27-30 CE), has obvious implications for its interpretation. Firstly, it is clear that a selective selection of rabbinic literature in service of condemning the Samaritans has not helped the interpretation of the parable (Levine 2014:100-101). Secondly, in terms of the three-step structure of the parable, the Samaritan arriving on the scene as the third character cannot be the 'major shock' or 'jarring surprise' in the parable.

Samaritans were seen as trustworthy Israelites, and therefore, it was, in essence, an Israelite who arrived, as expected.

But if the Samaritan is not the surprise in the parable, what then is it? The moment one looks past the so often stereotyped

18. The parable should not be interpreted in ethnic terms, as though the Samaritan was from a different people, hated by the Jews. They worshipped the same God was from a different people, hated by the Jews. They worshipped the same God differently albeit at a different place, also regarded the Pentateuch as a holy book,
and there were continual attacks and exclusions from both sides' (Schottroff 2006:135).
Samaritan as the key to the parable, the one who arrives at the scene is not first and foremost a despised Samaritan, but one of the most despised figures in the 1st-century advanced agrarian world, namely a merchant. That the Samaritan is a

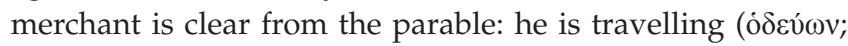
Lk 10:33), has to his disposal oil and wine (common items of

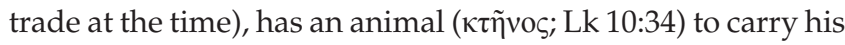
wares and most probably rode a second animal himself (Jeremias 1972:204; Oakman 2008:175). Also, as we have seen above, trade and contact between Samaritans and Jews were a normal part of life (see also Snodgrass 2008:347). It also seems that the Samaritan often travelled the road on which he helped the injured person, because he knows the innkeeper so well that he is willing to leave the injured person at his inn, and promise to pay whatever bill may be accrued until he is back. That the innkeeper accepts this arrangement most probably indicates that he knows the Samaritan because he has stayed in his inn previously on several occasions while travelling from and back to Samaria buying and selling his wares as a merchant or trader. ${ }^{19}$

Interestingly, only three interpreters of the parable have paid some attention to the Samaritan being a merchant. Jeremias (1972:204-205), Snodgrass (2008:347) and Barclay (1970:81) do mention that we most probably here have a character in the parable that is a merchant but do not make anything of it in their consequent interpretations. For them, the parable is still about a stereotyped Samaritan who is, in principle, an enemy of the Jews. Oakman (2008:173-180), on the other hand, argues that the Samaritan being a merchant cannot be ignored in the interpretation of the parable. According to him, 'Jewish peasants were hardly in sympathy with (those who) were engaged in commerce' (Oakman 2008:173). Oakman, however, in spite of his mentioning of the importance of the Samaritan being a merchant, also falls back in line with the default interpretation of the parable; it is a story about a Samaritan, who was also a trader. That he renames the parable to the 'Foolish Samaritan Parable' is clear evidence of his focus (see Oakman 2008:179).

What was the perception of merchants, persons who most probably belonged to the upper class (Miller 2007:66), in the social context in which Jesus told the parable? According to Sirach, people had little respect for merchants; they could hardly keep from wrongdoing, could not be trusted to give fair advice, only counsel for their own benefit, and were envious, cowards, unmerciful, lazy, idle persons and thieves (see Sirach 26:29; 37:7-11; 41:17-42:5). Philo, like Sirach also a Jewish writer and contemporary of Jesus, describes merchants as impure and foolish, persons who lack wisdom are barbaric slave dealers and injure those who purchase from them. Merchants, he states, practice one of the perverted occupations with only wicked purposes (see Philo, Cher. X.32-33; Migr.218.1-2; Ios.18-19; Spec. 4.193-194; Prob. 78).

19.See also Jeremias $(1972: 204-205)$ in this regard: The Samaritan was a merchant who often travelled on that specific road and earlier most probably made acquaintance with the innkeeper. Thus, because he comes there often, the innkeeper knows he will return. 
Turning to Greek and Roman writings, Herodotus of Halicarnassus places merchants below the swineherds (Hist. 2.164). Demosthenes is of the opinion that all merchants are dishonest, and names them as part of the unprincipled breed of citizens (see Demosthenes, Dionys. 1-4; Timocr. 1-12; Aristocr. 146-147), and The Testament of the Twelve Patriarchs 4.6 describes merchants as sly and evasive. Cicero (Off. 1.150.42) lists merchants as one of the vulgar trades, Herodianus, in his Ab excessu divi Marci 4.10.4c, depicts merchants as smugglers, and Diogenes Laertius laments the fact that the profession of the merchant is beneficial to one man but injurious to many (LivesPyrrho IX.81).

In the New Testament, James depicts merchants as godless and evil (Ja 4:13-16), and, according to the author of Revelation, merchants have grown rich with the wealth of their wantonness, gained wealth from the earth and deceive all nations by their sorcery (see Rv 18:3, 15 and 23). Finally, according to the gospel of Thomas, buyers and merchants will not enter the places of the father (Gos. Thom. 64.12). In nuce, for the 1st-century hearers of the parable, merchants personified the godless, symbolising everything that was unacceptable. ${ }^{20}$

Why this negative perception of merchants and mercantilism? First-century Mediterranean persons saw their existence as determined and limited by the natural and social resources of their immediate area and their world. This perception and belief lead to the idea that all goods available to a person were limited, the so-called concept of limited good (Malina 1981:89). In short, this meant that a larger share for any individual or group resulted in a smaller share for someone else. Linked to the concept of limited good was the peasants' perception of production and the mode of exchange (Rohrbaugh 1993:33). Peasant production was primarily for use rather than exchange, and the purpose of their labour was the maintenance of the well-being of their family and the village, not to create wealth. For peasants, it was therefore 'unnatural' to use money to buy commodities which one then resold at a profit. Profitmaking was seen as evil and socially destructive, 'a threat to the community and community balance' (Malina 1981:97). Because of this perception, rich people were seen as evil and thieves. To gain more than one needed was to steal from others, exactly what merchants did. A merchant therefore in principle was considered as dishonourable, immoral and basically godless (Malina 1981:98).

This then seems to be the surprise in the parable unexpectedly, it is a hated and despised person who saves a life, and above all, with the help of an innkeeper, also a trade that was despised by many in the time of Jesus. Contrary to the standard interpretation of the parable, the priest and Levite had no excuse such as 'uncleanness' or 'purity' to claim no responsibility to help the injured human. A human was lying in a ditch, dying, and to save a life was so important 20.This description of merchants and mercantilism is taken from Van Eck (2016:214-219) in the Jewish world that 'Jewish Law mandates that it override every other concern, including the Sabbath' (Levine 2014:94). ${ }^{21}$ Thus, it was their responsibility to save a life. But it is not them who saved a life. It is a despised person, one who takes life by being a threat to the peasantry's daily lives that focused on subsistence, with commercial trade being its biggest enemy, who gives life. One who normally exploits is the one who unexpectedly shows compassion. And above all, with the help of someone, an innkeeper, also somewhere on the list of despised persons.

\section{Reflection}

Firstly, the above reading of the parable fits with several other parables of Jesus in which the kingdom of God is likened to the actions of 'outsiders', the despised or the socalled unacceptable in society. In the parable of the Merchant (also known as the parable of the Pearl; Mt 13:45-46), it is the action of yet another merchant that symbolises the kingdom when he stops exploiting the poor. In the parable of the Lost Sheep (Lk 15:4-6), it is a despised shepherd ${ }^{22}$ who refrains from violence to make ends meet and to make sure that everyone has enough to eat, and in the parable of the Mustard Seed (Lk 13:14-18), the kingdom is likened to the actions of a human who plants a mustard seed in his garden, violating the law of diverse kinds and pollutes the garden. The garden becomes unclean, it is a symbol of chaos and it takes over; as the so-called unclean kingdom is doing. And in the parable of the Feast (Lk 14:16b23), it is a despised patron who nullifies the pivotal value of honour of the kingdom of Rome and the purity system of the kingdom of the Temple by inviting the socially and ritually (culturally) impure to his banquet. The above reading of the parable, I would argue, thus fits as an authentic parable of Jesus.

Secondly, read from this perspective, as said earlier, the parable has as its focus the breaking down of stereotypes that perpetuate discrimination and exclusion. This, I believe, the parable does on two levels. The first level is that of the first hearers of the parable. Here, we must remember that 1stcentury Mediterraneans were 'neither psychologically minded nor introspective ... stereotypes were the main way to get to know [the] other and to interact with them safely and predictably' (Malina \& Rohrbaugh 2003:379). Thus, instead of judging people individually and psychologically, stereotypical descriptions and explanations were used to describe people. These stereotypical descriptions were generalisations into which human behaviour had to fit; that is, 'individuals were judged in terms of values ascribed to the categories into which they fall' (Malina \& Rohrbaugh 2003:379). This means that, in the eye of the beholder, all merchants were seen as cowards, unmerciful, lazy, idle persons, thieves, dishonourable, immoral and basically godless. Above all, they lacked wisdom and practiced a trade

21.See 1 Maccabees 2:31-41, 2 Maccabees $6: 11$ and m. Shabbat 18.3, as quoted by Levine (2014:94)

22.See, for example, m. Qidd. 4.14 ('A man should not teach his son to be an ass-driver or a camel-driver, or barber or a sailor, or a herdsman or a shopkeeper, for thei craft is the craft of robbers') and m. B. Qam. 10.9 ('None may buy wool or milk from herdsmen, or wood or fruit from them that watch over fruit-trees'). 
that injured many. These stereotypes are broken down by Jesus in the parable.

In the end, it is the merchant who is merciful and honourable. Clearly, in the kingdom, it is not who you are that matters, but how you act. The manner in which the merchant acted was not the stereotyped expected exploitation, but to save a life. As such, the parable does not teach good neighbourliness or that one specific Samaritan can, contrary to all expectations, be 'good'; at a deeper level, the parable questions the way in which its hearers in principle interact with others, especially with those who were 'socially unacceptable'. As put by Levine (2011:123): 'The issue is not 'who is my neighbor?' but ... can we accept this disruption of our stereotypes?' What the parable asks is to rethink what it means to be human. At stake here for Jesus is not random acts of kindness, but a rethinking of what it means to be human, that is, to cherish and protect life without any exception.

The second level on which the parable breaks down stereotypes that perpetuate discrimination and exclusion is on the level of its modern hearers. Although we as moderns are psychologically minded and introspective, we also tend to construct our social reality by means of stereotypes. Stereotypes, the social psychologist Claude Steele states, are one way by which history is created and one of the many ways that effect present life. The reason for this is that all of us have many identities - our gender, our ethnicity, our age and our sexual orientation. And for each of these identities, we have negative stereotypes (see Steele 2010:1-14). Moreover, stereotypes almost always lead to prejudice, and soon become the way in which we think of and perceive the 'Other'. Stereotypes also normally feed into grand narratives of power and privilege that perpetuate social injustice and exclusion. This is what the parable challenges on the level of the reader, and calls for social justice in all its possible meanings.

Read from this perspective, the parable is a good example of what is meant by life-giving theology, or in the words of Volf and Croasmun, a theology that makes a difference (see Volf \& Croasmun 2019). According to Volf and Croasmun, a theology that matters is a theology that focuses on 'question of true life in the presence of God'; the 'truth and beauty of human existence in a world of justice, peace, and joy'. This is what academic theology also should be but largely is not, because it has 'lost the ability to address the most profound and important questions of human existence' (Volf \& Croasmun 2019:1-4). As the reading of the parable presented earlier notes, theology should yield 'beautiful, abundant, transgressive, and reconciling life' (Volf \& Croasmun 2019:6; [italics in the original]).

\section{The way forward}

Nowadays, however, the general sense is that 'theology isn't producing any genuine knowledge that accomplishes anything, that it trades with the irrationality of faith and is useless' (Volf \& Croasmun 2019:44). According to Volf and
Croasmun, there are several reasons for this state of affairs, of which I name for me the three most important ones: (1) academic theologians very often do not consider laypeople or the clergy relevant for their work, and therefore write for the guild, an audience that is at most times part of a narrow slice of a subfield; (2) in some circles, many theologians clutch nostalgically to past convictions and ways of life, as if the belief, practices and cultural mores of more than 500 years ago were of heavenly origin; and (3) the inability of theology, it seems, to address normative questions (see Volf and Croasmun 2019:35-59).

At the Department of New Testament and Related Literature, we want to heed to the call to practice life-giving theology. That is why my focus for the past 10 years have been the stories of a social prophet from Galilee as symbols of social and personal transformation. In the work of Dr Zoro Dube, the focus is first on Jesus the healer in a social-political context of imperial domination. In this context, the healings of Jesus are interpreted as acts that restored shalom and dignity. Secondly, with synergies from Ubuntu philosophy and Gabriel Marcel's theory of participation, he focuses on Jesus' concept of inclusiveness to advance a theoretical perspective that responds to the negative effects of globalisation such as raising nationalism, racism, immigration and xenophobia. Dr Hanré Janse van Rensburg, at her turn, studies eschatological literature, focusing on embodiment (the body is a location of religious expression), identity (e.g. gender, religious identity) and orality. As one of her methodological points of departure, she works with a hermeneutic of suspicion which premises that people and groups do not readily admit that they create, systemise and institutionalise their own social world and institutions while purporting that the created world and the institutions thereof are transcendentally 'given'. This process of religious legitimisation is called 'mystification', and results in a reification or naturalisation of institutions created by people. In other words, ideology is naturalised, and the socially engendered state of affairs is seen as permanent, natural, outside of time and directly revealed by God. To expose, for example, these dehumanising power interests, de-mystification and de-naturalisation are needed. In her work, she argues that eschatological texts aim to do exactly this: expose inter alia abusive power interests.

With these foci, we want to, as put by Volf and Croasmun (2019:33), counter 'taste-driven, individualised, unreflective ways of living' and help people to 'articulate, embrace, and pursue a compelling vision of a flourishing life for themselves and all creation'.

By doing this, we believe, we will continue not only the proud tradition of this department, that is, practicing a life-giving theology as a critical voice against narratives that breed systemic injustice such as exclusion and discrimination; but also a voice that calls for an open society with equal opportunities for all, a world in which all of creation can flourish.

A Samaritan merchant and his innkeeper friend save a life. After them, from an ideological point of view, they had 
friends in the department who practiced theology that gave new life to many. We, the current members of the department and faculty, consider ourselves also to be their friends.

\section{Acknowledgements Competing interests}

The author declares that no competing interests exist.

\section{Author's contributions}

I declare that I am the sole author of this research article.

\section{Ethical consideration}

This article followed all ethical standards for carrying out research without direct contact with human or animal subjects.

\section{Funding information}

This research received no specific grant from any funding agency in the public, commercial or not-for-profit sectors.

\section{Data availability statement}

Data sharing is not applicable to this article as no new data were created or analysed in this study.

\section{Disclaimer}

The views and opinions expressed in this article are those of the authors and do not necessarily reflect the official policy or position of any affiliated agency of the authors.

\section{References}

Bailey, K.E., 1983, Poet and peasant and through peasant eyes: A literary-cultural approach to the parables in Luke, William B. Eerdmans Publishing Company, Grand Rapids, MI.

Bailey, K.E., 2008, Jesus through middle Eastern eyes: Cultural studies in the gospels, IVP Academic, Downers Grove, IL.

Barclay, W., 1970, The parables of Jesus, Westminster John Knox Press, Louisville, KY. Blomberg, C.L., 2012, Interpreting the parables, InterVarsity Press, Downers Grove, IL. Crossan, J.D., 2012, The power of parable: How fiction by Jesus became fiction about Jesus, HarperOne, New York.
Danby, H., 2011, The Mishnah: Translated from the Hebrew with introduction and brief explanatory notes, Hendrickson Publishers, Peabody, MA.

Donahue, J.R., 1988, The gospel in parable: Metaphor, narrative, and theology in the Synoptic gospels, Fortress Press, Philadelphia, PA.

Fagenblat, M., 2011, 'The concept of neighbor in Jewish and Christian ethics', in A.-J. Levine \& M.Z. Brettler (eds.), The Jewish annotated New Testament: New Revised Standard Version translation, pp. 540-543, Oxford University Press, Oxford.

Hershkovitz, Y., 1940, 'Ha-Kutim be-Dibre ha-Tanna'im', Yavneh 2, 71-105.

Hjelm, I., 2000, The Samaritans and early Judaism: A literary analysis, Journal for the Study of the Old Testament Supplement Series, Sheffield Academic Press, Sheffield.

Hultgren, A.J., 2000, The parables of Jesus: A commentary, William B. Eerdmans Publishing Company, Grand Rapids, MI.

Jeremias, J., 1972, The parables of Jesus, SCM Press, London.

Levine, A.-J., 2011, 'Parable of the good Samaritan', in A.-J. Levine \& M.Z. Brettler (eds.), The Jewish annotated New Testament: New Revised Standard Version translation, p. 123, Oxford University Press, Oxford.

Levine, A.-J., 2014, Short stories by Jesus: The enigmatic parables of a controversial rabbi, HarperOne, San Francisco, CA.

Malina, B.J., 1981, The New Testament world: Insights from cultural anthropology, Westminster John Knox Press, Louisville, KY.

Malina, B.J. \& Rohrbaugh, R.L., 2003, Social-science commentary on the Synoptic gospels, Fortress Press, Minneapolis, MN.

Meier, J.P., 1991, A marginal Jew - Rethinking the historical Jesus: Probing the authenticity of the parables, Yale University Press, New Haven, CT.

Miller, R.J., 2007, 'The pearl, the treasure, the fool, and the cross, in E.F. Beutner (ed.), Listening to the parables of Jesus, Jesus Seminar Guides, pp. 65-82, Polebridge Press, Santa Rosa, CA.

Neusner, J., 2002, The Tosefta: Translated from the Hebrew, with a new introduction, Hendrickson Publishers, Peabody.

Oakman, D.E., 2008, Jesus and the peasants, Matrix: The Bible in Mediterranean Context, Cascade Books, Eugene, OR.

Rohrbaugh, R.L., 1993, 'A peasant reading of the talents/pounds: A text of terror' Biblical Theology Bulletin 23(1), 32-39. https://doi.org/10.1177/014610799 302300105

Schiffman, L.H., 1985, 'The Samaritans in Tannaitic halakhah', Jewish Quarterly Review 75(4), 323-350. https://doi.org/10.2307/1454401

Schottroff, L., 2006, The parables of Jesus, Augsburg Books, Minneapolis, MN.

Scott, B.B., 1989, Hear then the parable: A commentary on the parables of Jesus, Fortress Press, Minneapolis, MN.

Snodgrass, K.R., 2008, Stories with intent: A comprehensive guide to the parables of Jesus, William B. Eerdmans Publishing Company, Grand Rapids, MI.

Steele, C.M., 2010, Whistling Vivaldi: And other clues to how stereotypes affect us, W. W. Norton \& Company, Inc., New York.

Stein, R.H., 1981, An introduction to the parables of Jesus, Westminster Press, Philadelphia, PA.

Stiller, B.C., 2005, Preaching parables to postmoderns, Fortress Resources for Preaching, Fortress Press, Minneapolis, MN.

Van Eck, E., 2016, The parables of Jesus the Galilean: Stories of a social prophet, Matrix: The Bible in Mediterranean Context, Cascade Books, Eugene, OR.

Volf, M. \& Croasmun, M., 2019, For the life of the world: Theology that makes a difference, Theology for the Life of the World, Brazos Press, Grand Rapids, MI.

Wright, S.I., 2015, Jesus the storyteller, Westminster John Knox Press, Louisville, KY.

Zimmermann, R., 2015, Puzzling the parables of Jesus: Methods and interpretation, Fortress Press, Minneapolis, MN. 